\title{
Agroforestry Trees Improve Water Infiltrability in Semi-arid Tropical Parklands in Burkina Faso
}

\author{
Zomboudré Georges ${ }^{1}$, Ilstedt Ulrik ${ }^{2}$, Gnankambary Zacharia ${ }^{1}$, Nyberg Gert ${ }^{2}$, Somé Léopold ${ }^{1}$, Guinko Sita ${ }^{3}$ and \\ Malmer Anders ${ }^{2}$ \\ 1. Department of Natural Resource Management, Institute for Environment and Agricultural Research (INERA), 04 BP 8645 \\ Ouagadougou 04, Burkina Faso \\ 2. Department of Forest Ecology and Management, Swedish University of Agricultural Sciences, SE-901 83, Umeå, Sweden \\ 3. Laboratory of Biology and Plant Ecology, University of Ouagadougou, 03 BP 7021 Ouagadougou 03, Burkina Faso
}

\begin{abstract}
Maintaining appropriate levels of soil infiltrability is important for avoiding undesirable levels of surface runoff and erosion and for maintaining adequate rates of soil and groundwater recharge. This study was conducted with the aim of investigating the effects of Faidherbia albida (apple-ring acacia) and Vitellaria paradoxa (shea butter tree) trees and additions of inorganic fertilizer, leaves and compost on soil infiltrability in two agroforestry parkland systems in the western part of Burkina Faso. Infiltrability was measured before tilling both under and outside canopies of these trees, using tension disc and double-ring infiltrometers. The results show that infiltrability was 33\% higher on average under than outside canopies in both agroforestry parkland systems. The compost, leaves and inorganic fertilizer did not improve infiltrability significantly during the study period. More than $75 \%$ of the infiltrability estimates obtained using ring infiltrometers outside the canopies were lower than $40 \mathrm{~mm} / \mathrm{h}$. In contrast, less than $10 \%$ of those obtained from under canopies were lower than this. This could have highly significant effects on run-off, erosion and recharge since rain intensity measurements collected over three years at 30 min intervals showed that up to $35 \%$ of the annual precipitation fell with intensities $\geq 40 \mathrm{~mm} / \mathrm{h}$. The study demonstrates the potential of improving infiltrability and reducing surface runoff by managing trees appropriately in agroforestry systems in semi-arid tropics.
\end{abstract}

Key words: Agroforestry, infiltrability, semi-arid, rainfall intensity, Faidherbia albida, Vitellaria paradoxa.

\section{Introduction}

Soil infiltrability is a key variable of the soil's physical characteristics, which influences groundwater recharge, potential top soil loss by erosion and the partitioning of rainfall into slow flow and quick flow [1]. In the semi-arid tropics, where rainfall intensities can reach $60-120 \mathrm{~mm} / \mathrm{h}$ within a short time (a few minutes to an hour), surface runoff and soil erosion are common problems [2]. A recent review and meta-analysis showed the potential of using trees for improving soil infiltrability [3]. However, the general scarcity of studies made it impossible to generalize on interacting effects of trees in forest plantations and

Corresponding author: Zomboudré Georges, Ph.D., research fields: agroecology, soil and water management. agriculture with respect to edaphic situations, species and climate in the tropics [3]. In sub-Saharan Africa, farming is traditionally carried out in agroforestry parkland systems, where scattered trees are left standing after the original savannah woodland has been cleared [4]. In savannah regions with a long dry season, Vitellaria paradoxa C.F. Gaertn. and Faidherbia albida (Del.) A. Chev. are common indigenous woody plants of agroforestry parkland systems. In contrast to the permanently cultivated Faidherbia parkland systems, Vitellaria parklands pass through alternating cultivation and fallow phases [5]. The fallow periods are continuously being shortened, because of pressure for land [6], but farmers retain these two species in farmlands because they play important roles for their livelihoods. 
Notably, butter extracted from the kernels of Vitellaria nuts is used for local consumption and provides an important source of income for rural women [7]. Products of both species are also used in traditional medicine. However, due to the intensification of agriculture in the region, the parklands are contracting and in many cases the tree cover is diminishing [8].

Faidherbia is known for its reverse phenology [9]. This means that the tree has a green canopy, grows and fruits during the dry season, whereas leaves are shed after the first rains and its growth resumes only at the end of the wet season [10]. This phenological pattern reduces its competition with associated crops during the wet season and Faidherbia produces abundant fodder for livestock during the dry season [11]. The main crops grown in association with these two species are pearl-millet (Pennisetum glaucum), sorghum (Sorghum bicolor), maize (Zea mays), peanut (Arachis hypogaea), cotton (Gossypium hirsutum) and cowpea (Vigna unguiculata). Several studies have shown that these trees have beneficial effects on agricultural crops, notably that leaf litter from them promotes biological activity in the soil [12] and improves the physical properties of cultivated soil in terms of for example porosity, structure and water-holding capacity [13]. These are similar to the effects of applying compost to the fields [14]. Bayala et al. [15] concluded from a study carried out in the parklands of Burkina Faso that an application of leaf litter mulch from Parkia biglobosa and $V$. paradoxa prunings improved soil organic matter content as well as infiltrability (which it increased from $38 \mathrm{~mm} / \mathrm{h}$ to $87 \mathrm{~mm} / \mathrm{h}$ ). However, little is known about the effects of the canopies of these trees on the soil's hydraulic properties, e.g., infiltrability and sorptivity, although there is argument for published (e.g., Breman and Kessler [4]) and unpublished field data (e.g., Hansson [16]) that water infiltration rates can be higher under parkland canopies in semi-arid regions than outside the canopies.

This study was aimed to evaluate water infiltration parameters and other related soil properties according to the canopies of trees and inorganic fertilizer, leaves and compost application in typical $F$. albida and $V$. paradoxa agroforestry parklands.

\section{Materials and Methods}

\subsection{Study Site}

The study was carried out in the parklands around Dossi, a village located in the western end of Burkina Faso, West Africa $\left(11^{\circ} 26^{\prime} \mathrm{N}\right.$ and $\left.3^{\circ} 24^{\prime} \mathrm{W}\right)$ at an altitude of $350 \mathrm{~m}$. The parklands of Dossi are dominated by $F$. albida and $V$. paradoxa, the two major trees present in Sudanese and Sahelian zones. The density of trees in the study area was about 10-30 per hectare. The climate is South Soudanian, with a mean annual rainfall of $900 \mathrm{~mm}$ [17]. The soils are classified as Chromic Cambisols, according to the FAO/WRB classification system [18] in the fields with $F$. albida and Eutric Regosols in the fields with $V$. paradoxa. The surface layer has a silty-clay texture in the Faiderbia fields and a clayey-silt texture in Vitellaria fields. Deeper layers in both parklands are more clayey (Tables 1 and 2).

\subsection{Experimental Design}

Infiltration tests were performed on $56,4 \mathrm{~m} \times 6 \mathrm{~m}$ plots: 24 in $V$. paradoxa parkland and 32 in F. albida parkland. The plots were replicated in four different farmers's fields (treated as blocks in the statistical analysis) in each type of parkland. Within each farmer's fields, pairs of plots were distributed randomly with the restriction that one of the plots in each pair should be under and the other outside canopies of trees. These paired plots were treated in the statistical analysis as split-plots. Both plots in each pair were randomly assigned one of the following agricultural treatments: (a) control, (b) addition of 80 $\mathrm{kg}$ inorganic $\mathrm{N} / \mathrm{ha}$, (c) addition of compost, equivalent to $80 \mathrm{~kg} \mathrm{~N} / \mathrm{ha}$ and (d) addition of $V$. paradoxa leaves equivalent to $40 \mathrm{~kg} \mathrm{~N} / \mathrm{ha}$. The d treatment was solely applied to $F$. albida parkland. Therefore the F. albida 
Table 1 Means, standard error of the mean (SEM), medians, first and third quantiles (Q1 and Q3) of selected soil physical parameters under (u) and outside (o) canopies in Faidherbia albida parkland at Dossi village in Burkina Faso.

\begin{tabular}{|c|c|c|c|c|c|c|c|c|c|c|c|c|}
\hline \multirow{2}{*}{$\begin{array}{l}\text { Depth } \\
\text { (cm) }\end{array}$} & & \multicolumn{2}{|c|}{ Mean } & \multicolumn{2}{|c|}{ SEM } & \multicolumn{2}{|c|}{ Q1 } & \multicolumn{2}{|c|}{ Median } & \multicolumn{2}{|c|}{ Q3 } & \multirow{2}{*}{$\frac{p \text {-value }}{\mathrm{u} \text {-o }=0}$} \\
\hline & & o & $\mathrm{u}$ & o & $\mathrm{u}$ & o & $\mathrm{u}$ & o & $\mathrm{u}$ & o & $\mathrm{u}$ & \\
\hline \multirow{7}{*}{$0-10$} & $\mathrm{BD}$ & 1.3 & 1.2 & 0.02 & 0.02 & 1.2 & 1.2 & 1.3 & 1.2 & 1.4 & 1.3 & 0.055 \\
\hline & Total pores $(\%)$ & 50 & 53 & 1.2 & 0.8 & 47 & 51 & 50 & 53 & 54 & 56 & 0.055 \\
\hline & Macropores (\%) & 20 & 18 & 1.3 & 2.0 & 17 & 10 & 21 & 20 & 24 & 24 & 0.724 \\
\hline & PAW (\%) & 17 & 20 & 1.0 & 2.0 & 14 & 15 & 16 & 16 & 18 & 28 & 0.073 \\
\hline & Clay (\%) & 31 & 33 & 3.0 & 2.5 & 22 & 25 & 31 & 29 & 41 & 43 & 0.147 \\
\hline & Silt (\%) & 32 & 36 & 1.2 & 1.0 & 30 & 34 & 32 & 37 & 35 & 39 & 0.007 \\
\hline & Sand $(\%)$ & 37 & 31 & 3.2 & 2.0 & 28 & 24 & 38 & 33 & 43 & 37 & 0.014 \\
\hline \multirow{7}{*}{$10-20$} & $\mathrm{BD}$ & 1.3 & 1.2 & 0.0 & 0.0 & 1.2 & 1.2 & 1.3 & 1.2 & 1.3 & 1.2 & 0.845 \\
\hline & Total pores $(\%)$ & 52 & 53 & 1.0 & 0.9 & 49 & 52 & 52 & 53 & 53 & 55 & 0.845 \\
\hline & Macropores (\%) & 19 & 18 & 1.4 & 1.6 & 16 & 14 & 18 & 19 & 22 & 22 & 0.078 \\
\hline & PAW (\%) & 16 & 17 & 0.6 & 1.0 & 15 & 15 & 16 & 16 & 18 & 16 & 0.724 \\
\hline & Clay (\%) & 42 & 44 & 2.8 & 2.6 & 35 & 38 & 43 & 47 & 49 & 50 & 0.359 \\
\hline & Silt (\%) & 28 & 28 & 2.0 & 1.3 & 27 & 25 & 28 & 28 & 31 & 30 & 0.554 \\
\hline & Sand $(\%)$ & 30 & 28 & 2.45 & 2.32 & 24 & 21 & 30.4 & 28 & 35 & 31 & 0.363 \\
\hline \multirow{7}{*}{$20-30$} & $\mathrm{BD}$ & 1.3 & 1.4 & 0.0 & 0.0 & 1.2 & 1.3 & 1.3 & 1.4 & 1.4 & 1.3 & 0.41 \\
\hline & Total pores $(\%)$ & 49 & 48 & 1.1 & 1.3 & 45 & 44 & 49 & 47 & 52 & 50 & 0.41 \\
\hline & Macropores (\%) & 15 & 12 & 1.8 & 2.2 & 12 & 7 & 15 & 13 & 20 & 17 & 0.367 \\
\hline & PAW (\%) & 15 & 16 & 1.2 & 1.0 & 14 & 14 & 15 & 16 & 16 & 17 & 0.906 \\
\hline & Clay (\%) & 44 & 45 & 3.0 & 1.9 & 41 & 40 & 48 & 45 & 51 & 50 & 0.683 \\
\hline & Silt (\%) & 25 & 26 & 2.2 & 1.5 & 23 & 21 & 26 & 27 & 28 & 31 & 0.327 \\
\hline & Sand (\%) & 31 & 29 & 2.95 & 2.71 & 23 & 19 & 29.4 & 31 & 40 & 35 & 0.328 \\
\hline
\end{tabular}

The $p$-values represent Wilcoxon median tests of the difference between pairs of plots under vs outside is equal to zero.

NB: soil particles size distribution (clay, silt and sand) was analyzed using Robinson pipette method on air dried soil sieved on $2 \mathrm{~mm}$ mesh sieve and following the procedure described by Mathieu and Pieltain [19]; BD is soil bulk density determined using the mass of oven-dry soil present in the sampling cylinder $\left(500 \mathrm{~cm}^{3}\right)$ hammered into the soil; PAW is the available water capacity in the soil.

parkland had four more pairs of plots than the $V$. paradoxa parkland. Compost, extra leaves and inorganic fertilizer were applied for two consecutive years (2004 and 2005). The same experiment was also used and described in more detail, in studies of leaf decomposition and microbial respiration [20,21].

\subsection{Infiltration Measurements}

Infiltration tests were conducted in February 2006 during the dry season, in situ, using a plexiglas tension disc infiltrometer (model SW 080B, SDEC, France). One measurement was performed on each of the 56 plots. The disc of $20 \mathrm{~cm}$ diameter was separated and connected to a graduated water reservoir with a flexible tube. For each measurement a thin layer of moist fine sand was placed as contact material with the soil surface and the disc after gently scraping the surface roughness. Three tensions $(\mathrm{h}=-10,-5$ and 0 $\mathrm{cm}$ of water, corresponding to $1,0.5$ and $0 \mathrm{kPa}$, respectively) were applied at the soil-disc interface. The measurements were performed at the same place for each of the three pressure heads. Prior to each measurement a soil core was sampled near the disc to determine the soil's initial water content and after the measurement a core sample was also taken below the disc to obtain the final soil water content.

Since the scraping of the surface roughness and contact material for tension disc measurements may destroy crusts and macro pores in the surface. For comparison complementary, measurements were taken using the commonly applied double-ring infiltrometer method in areas adjacent to the disc infiltrometer measurements. The double-ring infiltrometer used for this purpose was made of two 
Table 2 Means, standard error of the mean (SEM), medians, first and third quantiles (Q1 and Q3) of selected soil physical parameters under (u) and outside (o) canopies in Vitellaria paradoxa parkland at Dossi village in Burkina Faso.

\begin{tabular}{|c|c|c|c|c|c|c|c|c|c|c|c|c|}
\hline \multirow{2}{*}{$\begin{array}{l}\text { Depth } \\
\text { (cm) }\end{array}$} & & \multicolumn{2}{|c|}{ Mean } & \multicolumn{2}{|c|}{ SEM } & \multicolumn{2}{|c|}{ Q1 } & \multicolumn{2}{|c|}{ Median } & \multicolumn{2}{|c|}{ Q3 } & \multirow{2}{*}{$\frac{p \text {-value }}{\mathrm{u} \text {-o }=0}$} \\
\hline & & o & $\mathrm{u}$ & o & $\mathrm{u}$ & o & $\mathrm{u}$ & o & $\mathrm{u}$ & o & $\mathrm{u}$ & \\
\hline \multirow{7}{*}{$0-10$} & $\mathrm{BD}$ & 1.3 & 1.3 & 0.04 & 0.02 & 1.3 & 1.3 & 1.3 & 1.2 & 1.4 & 1.3 & 0.726 \\
\hline & Total pores $(\%)$ & 50.6 & 51.8 & 1.6 & 0.8 & 48.5 & 51.1 & 50.9 & 52.0 & 52.7 & 52.6 & 0.726 \\
\hline & Macropores (\%) & 18 & 18 & 1.2 & 1.8 & 15.6 & 16 & 18 & 19 & 20 & 21 & 0.726 \\
\hline & PAW (\%) & 18 & 18 & 0.5 & 1.9 & 16.9 & 16 & 17 & 17 & 18 & 18 & 0.529 \\
\hline & Clay (\%) & 32 & 32 & 1.4 & 1.5 & 29 & 29 & 32 & 33 & 33 & 35 & 1 \\
\hline & Silt (\%) & 38 & 39 & 2.2 & 2.2 & 37 & 36 & 40 & 39 & 43 & 44 & 0.398 \\
\hline & Sand $(\%)$ & 30 & 29 & 1.9 & 2.3 & 26 & 25 & 29 & 29 & 33 & 34 & 0.777 \\
\hline \multirow{7}{*}{$10-20$} & $\mathrm{BD}$ & 1.3 & 1.3 & 0.0 & 0.0 & 1.2 & 1.3 & 1.3 & 1.3 & 1.3 & 1.4 & 0.042 \\
\hline & Total pores $(\%)$ & 53 & 50 & 0.9 & 1.0 & 51 & 48 & 52 & 50 & 55 & 52 & 0.042 \\
\hline & Macropores (\%) & 18 & 17 & 1.3 & 1.6 & 17 & 16 & 19 & 18 & 21 & 19 & 0.441 \\
\hline & PAW (\%) & 18 & 17 & 1.1 & 1.7 & 16 & 14 & 18 & 16 & 20 & 18 & 0.363 \\
\hline & Clay (\%) & 33 & 36 & 3.1 & 3.8 & 30 & 30 & 34 & 32 & 39 & 42 & 0.6 \\
\hline & Silt (\%) & 40 & 30 & 3.7 & 1.9 & 35 & 26 & 39 & 29 & 43 & 32 & 0.993 \\
\hline & Sand $(\%)$ & 27 & 34 & 1.7 & 3.4 & 23.5 & 30.4 & 25.5 & 32.3 & 31.3 & 42 & 0.054 \\
\hline \multirow{7}{*}{$20-30$} & $\mathrm{BD}$ & 1.3 & 1.3 & 0.0 & 0.0 & 1.2 & 1.3 & 1.3 & 1.4 & 1.3 & 1.4 & 0.059 \\
\hline & Total pores $(\%)$ & 52 & 48 & 1.5 & 1.4 & 49.7 & 46 & 53 & 49 & 54 & 51 & 0.059 \\
\hline & Macropores (\%) & 17 & 14 & 1.9 & 1.7 & 13.6 & 11 & 17 & 15 & 19 & 17 & 0.294 \\
\hline & PAW (\%) & 18 & 17 & 1.3 & 1.7 & 15.8 & 13 & 16 & 16 & 21 & 17 & 0.624 \\
\hline & Clay (\%) & 40 & 39 & 2.8 & 3.5 & 34.8 & 34 & 39 & 37 & 43 & 45 & 1 \\
\hline & Silt (\%) & 38 & 31 & 2.9 & 2.2 & 34.3 & 27 & 37 & 30 & 43 & 33 & 0.021 \\
\hline & Sand $(\%)$ & 22 & 30 & 1.7 & 4.3 & 19.1 & 21 & 20.6 & 28.4 & 24 & 35.2 & 0.08 \\
\hline
\end{tabular}

The $p$-values represent Wilcoxon median tests of the difference between pairs of plots under vs outside is equal to zero.

NB: soil particles size distribution (clay, silt and sand) was analyzed using Robinson pipette method on air dried soil sieved on $2 \mathrm{~mm}$ mesh sieve and following the procedure described by Mathieu and Pieltain [19]; BD is soil bulk density determined using the mass of oven-dry soil present in the sampling cylinder $\left(500 \mathrm{~cm}^{3}\right)$ hammered into the soil; PAW is the available water capacity in the soil.

concentric rings, with internal diameters of $28 \mathrm{~cm}$ and $53 \mathrm{~cm}$. A constant head of $5 \mathrm{~cm}$ of water was maintained in the inner ring, while the free water surface of $5 \mathrm{~cm}$ was ascertained in the outer.

\subsection{Rain Measurements}

Rainfall at the site was measured with a tipping bucket pluviometer (model ARG 100, Campbell, UK; $0.202 \mathrm{~mm} / \mathrm{tip}$ ) at $30-\mathrm{min}$ intervals and recorded using a Campbell CR10× logger (Campbell Scientific, Logan, Utah, USA). The data recorded for each year have been used to produce series of rain depths integrated over various time steps, e.g., $0.5,1$ and $2 \mathrm{~h}$, which provide information on rain intensities. These intensities were ranked in increasing order for each of the three years 2004, 2005 and 2006 and used to calculate cumulative distributions of percentages of the total annual rainfall versus intensity.

\subsection{Infiltration Modeling}

The infiltration data were fitted to the model developed by Philip [22]. For the one-dimensional infiltration data, he proposed:

$$
I(t)=S \sqrt{t}+A t
$$

where $I$ is the cumulative infiltration $(L), t$ is time $(T)$, $S$ is the sorptivity $\left(L / t^{1 / 2}\right)$ and A is a constant called the transmissivity $(L / t)$ or steady state infiltrability [23]. This equation was assumed applicable to double ring infiltrometer measurements.

For the three-dimensional infiltration data obtained from a disc infiltrometer, $K\left(h_{0}\right)$ values were obtained from the steady infiltration rate $Q\left(h_{0}\right)(L / t)$ at successive supply pressures $\left(h_{0}\right)$ [24] using the 
solution presented by Wooding [25] based on Gardner's exponential hydraulic conductivity function [26]:

$$
Q\left(h_{0}\right)=K\left(h_{0}\right)\left[1+\frac{4}{\pi r \alpha}\right]=K_{s} \exp \left(\alpha h_{0}\right)\left[1+\frac{4}{\pi r \alpha}\right]
$$

where $K_{s}$ is the field-saturated hydraulic conductivity $(L / t)$ and $\alpha$ is the exponential slope $(1 / L)$. If $\alpha$ is assumed to be constant over the range of $h$ [27], it can be determined according to:

$$
\alpha=\frac{\ln \left[Q\left(h_{2}\right) / Q\left(h_{1}\right)\right]}{h_{2}-h_{1}}
$$

This requires measuring the steady state infiltration rate at two different matric potentials $\left(h_{1}\right.$ and $\left.h_{2}\right)$. Once $\alpha$ is known and $Q$ measured for a given matric potential, it is possible to calculate $K_{s}$ using Eq. (2). Then, $K_{s}$ for the soil surface was used to approximate steady state infiltrability. Since sorptivity is defined for an initially dry soil, it was determined during the first stage of infiltration according to Philip's equation and Haverkamp et al. [28].

\subsection{Statistics}

Differences in treatment effects were analyzed by ANOVA using the general linear model (GLM) implemented in Minitab Release 14 (Minitab Inc.). The following split-plot model was applied separately for the two parkland species:

$$
y_{i j k}=\mu+\alpha_{i}+\beta_{k}+\gamma_{i k}+b_{j}+c_{i j}+d_{k j}+\varepsilon_{i k j}
$$

where $\mu$ : the grand mean; $i$ : the canopy effect; $k$ : the effect of the different application treatments; $j$ : the effect of the main blocks. The residuals were tested for homogeneity and normality, and data were log-transformed if necessary. Differences were deemed significant if $p<0.05$.

\section{Results}

\subsection{The Effects of Canopies and Treatments on Infiltrability}

Steady state infiltrability and $K_{s}$ values obtained in the two parklands were higher under canopies than in open fields in both parklands (Tables 3 and 4). None of the fertilizer, extra leaves or compost treatments had any significant effect. There were also no significant interaction between canopy and treatments. Sorptivity did not appear to be significantly affected by any of the treatments.

The average steady state infiltrability outside and under canopies was $40 \mathrm{~mm} / \mathrm{h}$ and $53 \mathrm{~mm} / \mathrm{h}$, respectively, according to the ring infiltrometer measurements (Tables 3 and 4). Corresponding $K_{s}$ values obtained with the tension infiltrometer were $36 \mathrm{~mm} / \mathrm{h}$ and $44 \mathrm{~mm} / \mathrm{h}$, respectively (Tables 3 and 4). More than $75 \%$ of the infiltrability estimates obtained using the ring infiltrometer outside the canopies were lower than $40 \mathrm{~mm} / \mathrm{h}$. In contrast, less than $10 \%$ of those obtained from under canopies were lower than this. Correspondingly, $40 \%$ and $90 \%$ of the measurements were below $50 \mathrm{~mm} / \mathrm{h}$ under and outside canopies, respectively (Fig. 1). There were no measurements outside canopies above $60 \mathrm{~mm} / \mathrm{h}$, while $20 \%$ of the measurements under canopies were higher.

At the two lowest tensions $(-5 \mathrm{~cm}$ and $-10 \mathrm{~cm})$ used in the disc infiltrometer measurements no significant difference in steady state infiltrability between sites under canopies and outside canopies was detected (Tables 3 and 4) and the infiltrability was about 20 $\mathrm{mm} / \mathrm{h}$ and $10 \mathrm{~mm} / \mathrm{h}$, respectively. The calculated $\alpha$ value describing the slope of the regression of infiltrability versus tension was not affected by either the fertilizer or compost treatments.

\subsection{The Relationship between Rain Intensity and Steady State Infiltrability}

The amounts recorded during the rainy seasons (May to October) of 2004, 2005 and 2006 were 610, 878 and $986 \mathrm{~mm}$, respectively, representing both dry and wet years. The duration of most rainfall events ranged from $0.5 \mathrm{~h}$ to $2 \mathrm{~h}$, with varying degrees of intensity. Up to $40 \%$ and $20 \%$ of the annual precipitation fell at intensities in excess of $40 \mathrm{~mm} / \mathrm{h}$ and $60 \mathrm{~mm} / \mathrm{h}$, respectively, in events lasting at least $0.5 \mathrm{~h}$ and the corresponding values for events lasting at least $1 \mathrm{~h}$ were $20 \%$ and $5 \%$, respectively (Fig. 2). 
Table 3 Means, standard error of the mean (SEM), medians, first and third quantiles (Q1 and Q3) of hydrological parameters under (u) and outside (o) canopies in F. albida parkland at Dossi village in Burkina Faso.

\begin{tabular}{|c|c|c|c|c|c|c|c|c|c|c|c|}
\hline & \multicolumn{2}{|c|}{ Mean } & \multicolumn{2}{|c|}{ SEM } & \multicolumn{2}{|c|}{ Q1 } & \multicolumn{2}{|c|}{ Median } & \multicolumn{2}{|c|}{ Q3 } & \multirow{2}{*}{$\frac{p \text {-value }}{\mathrm{u} \text {-o }=0}$} \\
\hline & o & $\mathrm{u}$ & o & $\mathrm{u}$ & o & $\mathrm{u}$ & o & $\mathrm{u}$ & o & $\mathrm{u}$ & \\
\hline Dksat $(\mathrm{mm} / \mathrm{h})$ & 27.5 & 35.2 & 1.4 & 1.7 & 23.0 & 30.9 & 27.6 & 34.5 & 31.1 & 37.9 & 0.008 \\
\hline Dk5 (mm/h) & 14.7 & 15.4 & 0.9 & 0.8 & 11.0 & 13.5 & 15.3 & 15.8 & 17.6 & 17.6 & 0.737 \\
\hline $\mathrm{Dk} 10(\mathrm{~mm} / \mathrm{h})$ & 7.9 & 6.9 & 0.6 & 0.5 & 5.4 & 6.1 & 8.3 & 6.9 & 10.0 & 8.4 & 0.196 \\
\hline$\alpha(1 / \mathrm{mm})$ & 0.1 & 0.2 & 0.01 & 0.01 & 0.1 & 0.1 & 0.1 & 0.2 & 0.2 & 0.2 & 0.003 \\
\hline Ds $\left(\mathrm{mm} / \mathrm{h}^{1 / 2}\right)$ & 85.3 & 116.0 & 6.7 & 14.6 & 63.8 & 76.5 & 81.1 & 96.6 & 102.2 & 151.5 & 0.014 \\
\hline $\operatorname{Rinf}(m m / h)$ & 39.4 & 55.2 & 1.3 & 2.7 & 36.0 & 48.2 & 38.2 & 54.0 & 41.8 & 64.6 & 0.001 \\
\hline $\operatorname{Rs}\left(\mathrm{mm} / \mathrm{h}^{1 / 2}\right)$ & 91.5 & 80.2 & 13.2 & 8.5 & 50.7 & 66.7 & 71.3 & 73.7 & 138.0 & 99.1 & 0.66 \\
\hline OM (\%) & 2.0 & 2.6 & 0.1 & 0.1 & 1.8 & 2.4 & 1.8 & 2.7 & 2.5 & 2.8 & 0.002 \\
\hline
\end{tabular}

The $p$-values represent Wilcoxon median tests of the difference between pairs of plots under vs outside is equal to zero.

Dk10, Dk5 and Dksat are soil hydraulic conductivity with the disc at tensions of $1(-10 \mathrm{~cm}), 0.5(-5 \mathrm{~cm})$ and $0(0 \mathrm{~cm}) \mathrm{kPa}$, respectively; $\alpha$ is a constant; Ds is soil sorptivity measured with the disc; Rinf is the soil hydraulic conductivity with the two concentric rings at the constant head of $5 \mathrm{~cm}$ of water in the inner ring, while the free water surface of $5 \mathrm{~cm}$ was ascertained in the outer; Rs is soil sorptivity measured with the two concentric rings; OM is soil organic matter determined by the Walkley and Black [29] method.

Table 4 Means, standard error of the mean (SEM), medians, first and third quantiles (Q1 and Q3) of hydrological parameters under (u) and outside (o) canopies in V. paradoxa parkland at Dossi village in Burkina Faso.

\begin{tabular}{|c|c|c|c|c|c|c|c|c|c|c|c|}
\hline & \multicolumn{2}{|c|}{ Mean } & \multicolumn{2}{|c|}{ SEM } & \multicolumn{2}{|c|}{ Q1 } & \multicolumn{2}{|c|}{ Median } & \multicolumn{2}{|c|}{ Q3 } & \multirow{2}{*}{$\frac{p \text {-value }}{\mathrm{u}-\mathrm{o}=0}$} \\
\hline & o & $\mathrm{u}$ & $\mathrm{o}$ & $\mathrm{u}$ & o & $\mathrm{u}$ & o & $\mathrm{u}$ & o & $\mathrm{u}$ & \\
\hline Dksat $(\mathrm{mm} / \mathrm{h})$ & 24.3 & 29.1 & 1.6 & 1.9 & 19.5 & 23.5 & 23.7 & 29.0 & 29.9 & 32.3 & 0.055 \\
\hline $\mathrm{Dk} 5$ (mm/h) & 10.9 & 13.0 & 0.9 & 0.8 & 8.5 & 10.6 & 10.0 & 12.4 & 12.2 & 15.0 & 0.021 \\
\hline $\operatorname{Dk} 10(\mathrm{~mm} / \mathrm{h})$ & 5.0 & 5.9 & 0.6 & 0.4 & 3.5 & 4.6 & 4.8 & 5.7 & 5.3 & 7.1 & 0.142 \\
\hline$\alpha(1 / \mathrm{mm})$ & 0.2 & 0.2 & 0.01 & 0.01 & 0.1 & 0.1 & 0.2 & 0.2 & 0.2 & 0.2 & 1 \\
\hline Ds $\left(\mathrm{mm} / \mathrm{h}^{1 / 2}\right)$ & 77.4 & 90.7 & 8.6 & 10.9 & 54.8 & 64.1 & 76.2 & 78.9 & 86.1 & 128.0 & 0.556 \\
\hline $\operatorname{Rinf}(\mathrm{mm} / \mathrm{h})$ & 41.9 & 50.7 & 2.1 & 2.6 & 37.6 & 43.6 & 39.6 & 48.8 & 43.2 & 57.4 & 0.005 \\
\hline $\operatorname{Rs}\left(\mathrm{mm} / \mathrm{h}^{1 / 2}\right)$ & 58.4 & 55.6 & 6.7 & 9.1 & 37.2 & 27.5 & 54.6 & 53.2 & 77.9 & 88.3 & 0.556 \\
\hline $\mathrm{OM}(\%)$ & 2.5 & 3.5 & 0.2 & 0.2 & 2.0 & 2.9 & 2.6 & 3.4 & 2.9 & 4.0 & 0.007 \\
\hline
\end{tabular}

The $p$-values represent Wilcoxon median tests of the difference between pairs of plots under vs outside is equal to zero.

Dk10, Dk5 and Dksat are soil hydraulic conductivity with the disc at tensions of $1(-10 \mathrm{~cm}), 0.5(-5 \mathrm{~cm})$ and $0(0 \mathrm{~cm}) \mathrm{kPa}$, respectively; $\alpha$ is a constant; Ds is soil sorptivity measured with the disc; Rinf is the soil hydraulic conductivity with the two concentric rings at the constant head of $5 \mathrm{~cm}$ of water in the inner ring, while the free water surface of $5 \mathrm{~cm}$ was ascertained in the outer; Rs is soil sorptivity measured with the two concentric rings; OM is soil organic matter determined by the Walkley and Black [29] method.

\section{Discussion}

Soil steady state infiltrability was on average $33 \%$ higher under than outside canopies of both studied parkland species, in accordance with expectations since soil under canopies receives more organic material from shed leaves, dead branches and roots [30]. In addition, when dead tree roots decompose they leave macro pore channels through which water can easily flow [31] and higher amounts of faeces and urine are deposited under trees than in open fields by birds perching in the tree crowns and livestock grazing in their shade [32].

The soil organic matter affects the soil aggregate stability and thus its susceptibility to form surface crusts [33], while the increased carbon and nutrient concentrations stimulate macro-fauna, further improving the soil structure. Accordingly, significant positive relationships between infiltrability and soil organic matter contents were found for both parkland types examined (Fig. 3). However, the slope of the 


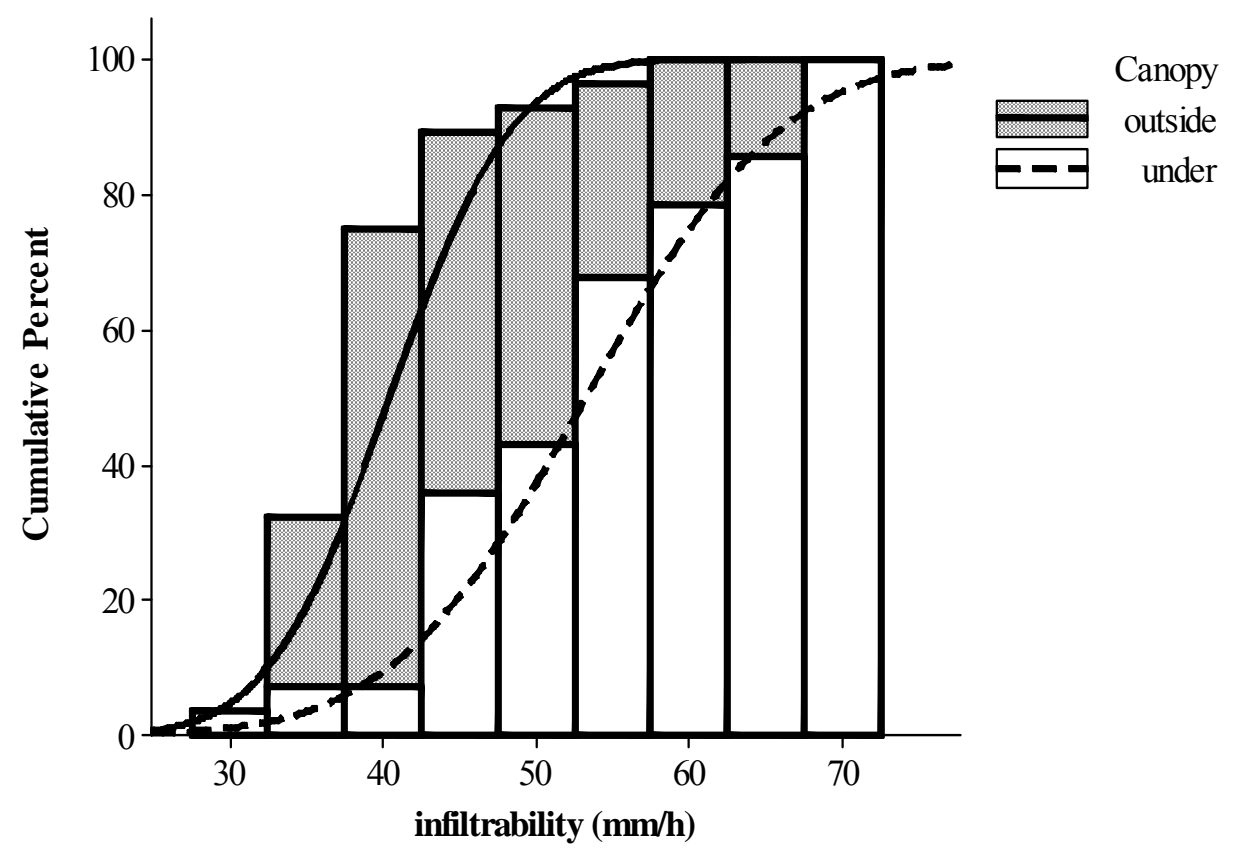

Fig. 1 Frequencies of steady state infiltrability obtained using the double ring infiltrometer under and outside canopies in parklands at Dossi village in Burkina Faso.

Data from Vitellaria paradoxa and Faidherbia albida parklands are combined.

regression was steeper for $F$. albida than for $V$. paradoxa, possibly because $F$. albida leaves contain more nitrogen and other nutrients, thus decomposing more rapidly and limiting the accumulation of soil organic matter [34]. Interestingly, the lower soil organic matter content does not seem to result in lower infiltrability, indicating that the reduction in infiltrability may not be a direct effect of the organic material, but rather due to the bioturbation and soil aggregation associated with its decomposition, corroborating findings presented and discussed by Malmer et al. [35].

This study compared the infiltrability under and outside canopies in parklands with tree densities of 10-30 trees/ha. The trees also probably affect the infiltrability beyond their canopies. Therefore, parklands with relatively high densities of trees may generally have soils with higher infiltrability than those with fewer trees, even if the differences between sites under canopies and outside canopies could be less pronounced. In accordance Ouattara et al. [36] recorded steady state infiltrability values for treeless fields in parkland in Bondoukuy, same region of Burkina Faso, ranging from $14 \mathrm{~mm} / \mathrm{h}$ to $25 \mathrm{~mm} / \mathrm{h}$ on Ferric Luvisol and from $36 \mathrm{~mm} / \mathrm{h}$ to $142 \mathrm{~mm} / \mathrm{h}$ on nearby Lixisols. The steady state infiltrability under canopies of parkland trees in study were comparable to those previously found in lightly grazed savanna woodland in Burkina Faso by Savadogo et al. [37], while those of areas outside canopies seemed lower. In uncultivated savanna woodlands under light and moderate grazing, the cited authors measured infiltratrability of $49 \mathrm{~mm} / \mathrm{h}$ to $123 \mathrm{~mm} / \mathrm{h}$, the highest values being found in areas that had been protected from fire for 12 years. At sites exposed to 'very heavy grazing' (by eight animals per day and hectare) the infiltrability values they obtained were $21 \mathrm{~mm} / \mathrm{h}$ and $16 \mathrm{~mm} / \mathrm{h}$ for areas with and without fire protection, respectively. 


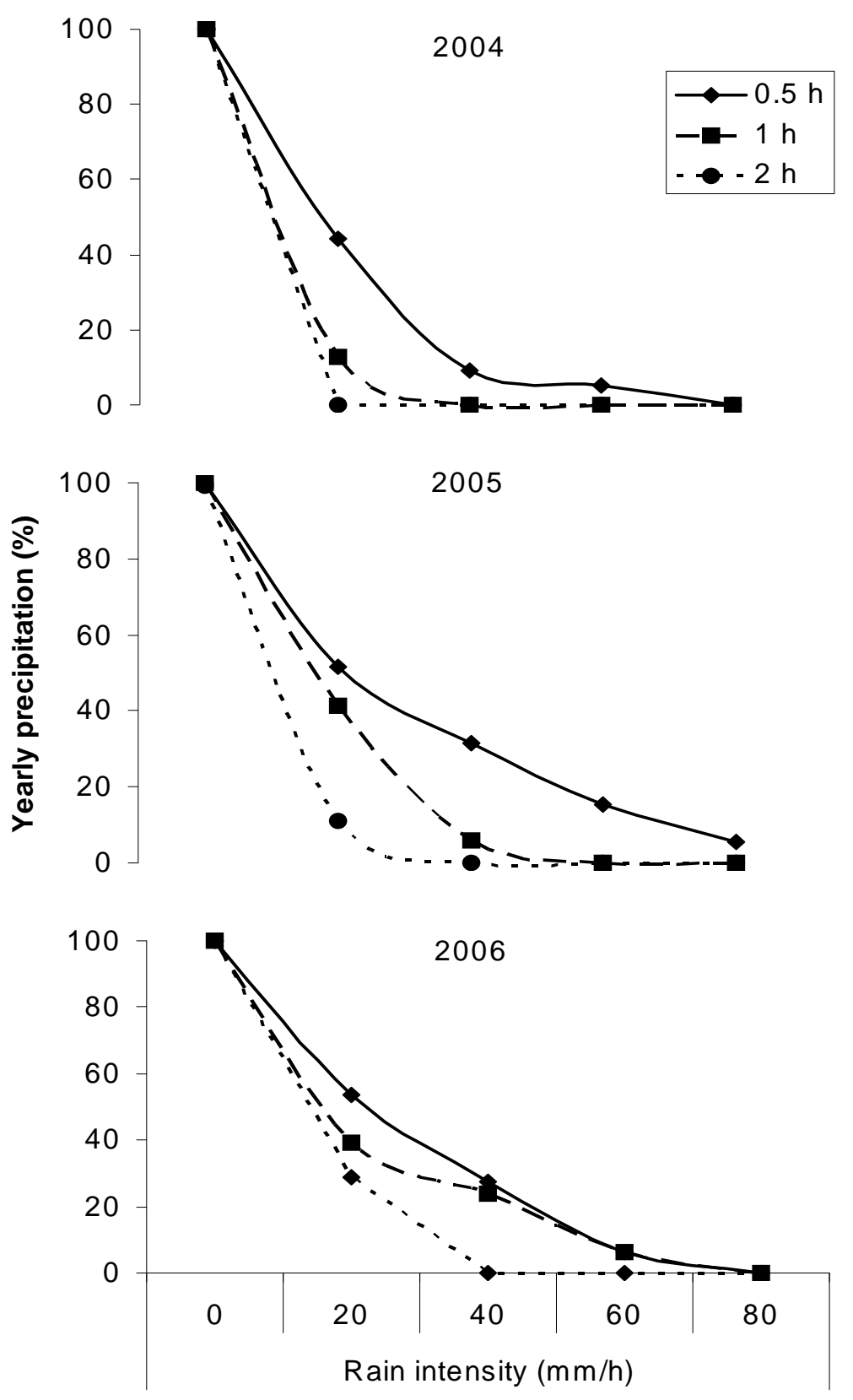

Fig. 2 Percentages of yearly rainfall in 2004, 2005 and 2006 at Dossi village in Burkina Faso, falling at intensities exceeding $0,20,40,60$ and $80 \mathrm{~mm} / \mathrm{h}$ in periods of at least $0.5,1$ and $2 \mathrm{~h}$.

In contrast to the canopy effect, the applications of compost, additional leaves or fertilizer did not significantly improve the soil infiltrability, possibly because of the short time between treatments and assessment. The additional leaves and compost were only applied twice to the plots (in 2004 and 2005) and probably did not cause detectable difference, relative to the inputs from the standing trees over the preceding 20 years or more [16]. Bayala et al. [15] examined mulched P. biglobosa and $V$. paradoxa plots over two years and noted that infiltrability tended to increase at sites where leaf litter was added, but the differences were not always significant at the $95 \%$ probability level. Similar trends of varying levels of significance have been found following the application of compost in cropping fields on Luvisol 


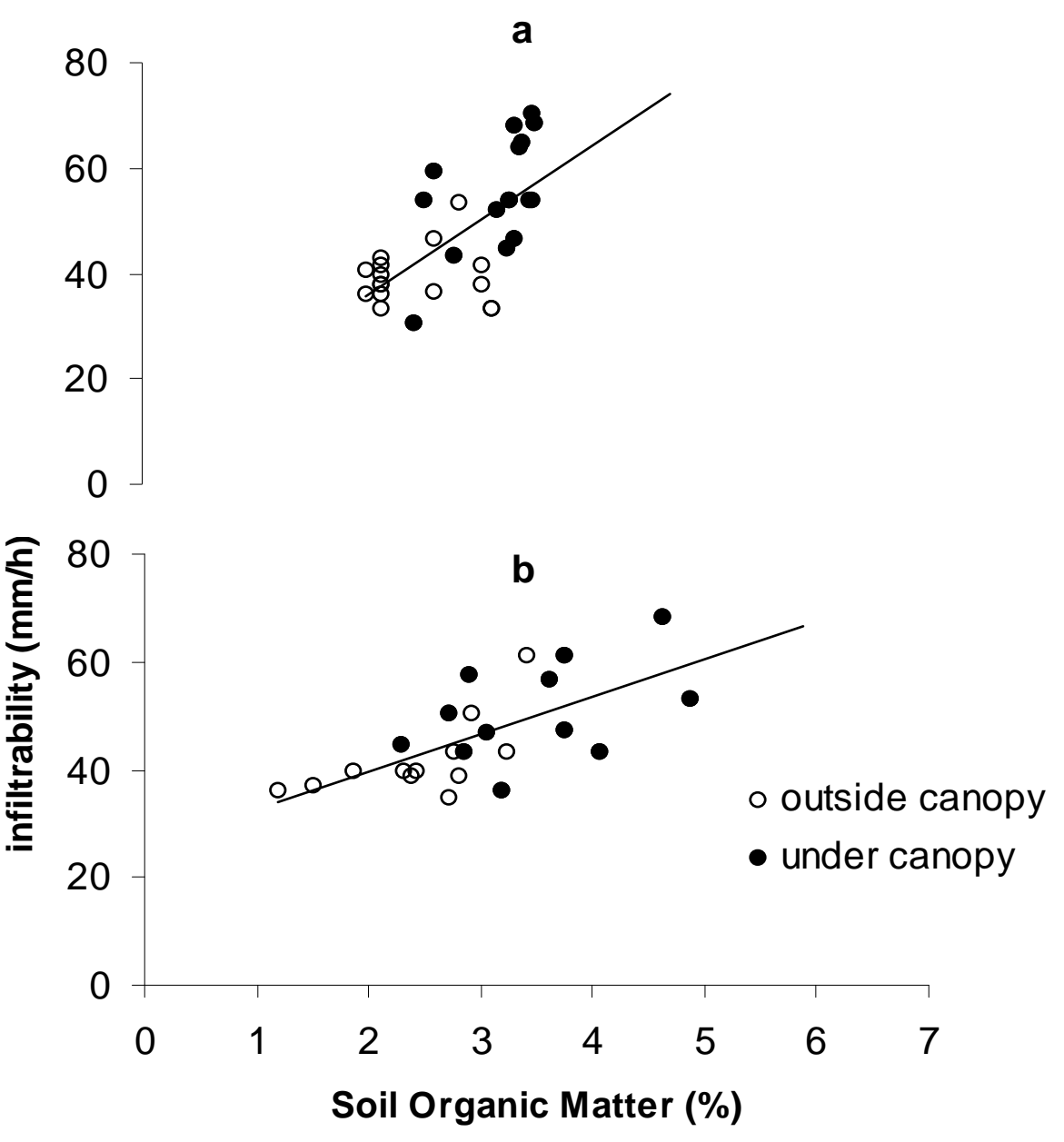

Fig. 3 Relationship between mean soil organic matter (0-10 cm depth) and infiltrability in a) F. albida $\left(R^{2}=0.42 ; p<0.05\right)$ and b) V. paradoxa $\left(R^{2}=0.44 ; p<0.05\right)$ parklands at Dossi village in Burkina Faso.

and Lixisol after three years of application [38].

A ring infiltrometer generally provides higher measurements of infiltrability than a tension disc, partly because the latter provides estimates based on three-dimensional flows, while those of the former are based on one-dimensional ponded infiltration. In addition, according to Reynolds and Elrick [24] insertion of a ring infiltrometer into the soil may alter the soil's hydraulic properties by causing some of the macro-structure to collapse, cutting off pores by the ring wall, matrix compression of wet soils, or shattering of dry soils. For a disc infiltrometer, on the other hand, a sand layer is needed to connect the disc and soil, which may potentially block larger pores. This action may reduce the variability of the measurements if larges pores are present in different locations. Accordingly, disc infiltrometer measurements seemed to have less total variability than the ring infiltrometer measurements.

However, both types of infiltrometer are likely to provide higher estimates of infiltrability of crust-prone soils than the infiltration rates of water falling in high intensity rains and infiltrability measurements provided by rainfall simulators. The differences in estimates of infiltrability obtained with the different supply pressures applied with the disc infiltrometer (Tables 3 and 4) are related to the arrangement and distribution of microscopic pores; variables that depend (inter alia) on the original soil, farming practices and rainfall events [38]. Since significant 
differences between sites under canopies and outside canopies were only found with the $0 \mathrm{~cm}$ supply pressure in this experiment the trees presumably increase the macro porosity, without substantially changing the distribution of the smaller pores.

A change in infiltrability may, or may not, lead to increased soil and groundwater recharge. For surface runoff to occur, the rainfall intensity needs to be higher than the infiltrability. The three years of rainfall intensity measurements clearly show that large proportions of the annual rainfall occur in events with intensities exceeding the measured infiltrability. For example, up to $30 \%$ of the yearly rain fell at intensities exceeding $40 \mathrm{~mm} / \mathrm{h}$ (Fig. 2). Similar values have been recorded in the Sahel (Mali) by Hoogmoed and Stroosnijder [39], who found that $20 \%-40 \%$ of the annual rainfall in a three-year period occurred in periods with intensities exceeding $50 \mathrm{~mm} / \mathrm{h}$. Taking this rain intensity and assuming the variability in infiltrability in the study as representing the spatial variability, the infiltrability data (Tables 3 and 4) indicate that all of the rain would infiltrate the soil in $60 \%$ of the area under trees without surface runoff, but only $10 \%$ of the area outside tree canopies. In the first case it is quite possible that runoff generated in patches with lower infiltration can infiltrate in adjacent patches with higher infiltration. In the other case this is less likely. The occurrence of infiltration excess overland flow is also supported by personal observations of runoff in the area by the authors and local farmers.

In the semi-arid tropics the soils' ability to absorb the annual precipitation within the short rainy season is likely to be important for groundwater recharge and plant growth. Hence, the trees may play important roles in limiting surface runoff and increasing groundwater recharge. However, it is possible that the increased water infiltration induced by the trees may be offset by their transpiration. They may also have species-specific effects on these variables. For instance, it has been shown that crop growth is higher under F. albida canopies, especially in dry years [34], but crops grew less well under $V$. paradoxa canopies, at least in wet years. For groundwater recharge an important consideration is the possibility that water may 'by-pass' the root zone responsible for most transpiration by flowing in macro pores [1]. Such macro pores are often present in the hard pan underlying the cultivated surface soil (pers. obs.), but it is not known from studies that have examined the effect of trees on the abundance or function of these macro pores in parklands.

\section{Conclusions}

This study was conducted to determine the effects of $F$. albida and $V$. paradoxa trees on soil infiltrability and sorptivity in farmers' fields at Dossi, Burkina Faso and compare them to the effects of various compost treatments. Infiltrability under the canopies of trees scattered in the farmlands was on average $33 \%$ higher than outside canopies. The infiltrability at sites outside the canopies were generally lower than prevailing rainfall intensities, indicating that the higher infiltrability under trees could be important for preventing surface runoff and increasing groundwater recharge. Neither infiltrability nor sorptivity was significantly influenced by the compost, leaf mulch and fertilizer treatments in this short-term on-farm experiment. In typical parkland, trees are rarely planted which have resulted in an uneven distribution of the trees and consequently an inappropriate canopy cover. Water infiltrability in these parklands could be improved through management of the tree distribution to optimize the effect of the canopies. Studies investigating the effect of compost, leaf much and fertilizer applications on the soil's hydraulic properties should be considered in a wide range of parklands.

\section{Acknowledgments}

Funding for this study was provided by the Swedish International Development Cooperation Agency (SIDA/SAREC). Thanks a lot the farmers in Dossi for 
their permission to use their fields and their participation in the field experiment. Thanks also go to Korodjouma Ouattara, Linnea Hansson and the technicians Adama Ouédraogo and Bakary Magané of INERA for their assistance.

\section{References}

[1] Bonell, M. 1993. "Progress in the Understanding of Runoff Generation Dynamics in Forests." Journal of Hydrology 150: 217-75.

[2] Sivakumar, M. V. K., and Gnoumou, F. 1987. "Agroclimatology of West Africa: Burkina Faso." ICRISAT Information Bulletin 23: 1-62.

[3] Ilstedt, U., Malmer, A., Verbeeten, E., and Murdiyarso, D. 2007. "The Effect of Afforestation on Water Infiltration in the Tropics: A Systematic Review and Meta-analysis." Forest Ecology and Management 251: 45-51.

[4] Breman, H., and Kessler, J. J. 1995. Woody Plants in Agroecosystems of Semi-arid Regions. Berlin, Heidelberg: Springer Verlag, 368.

[5] Okullo, J. B. L., Hall, J. B., and Obua, J. 2004. "Leafing, Flowering and Fruiting of Vitellaria paradoxa subsp. Nilotica in Savanna Parklands in Uganda." Agroforestry Systems 60 (1): 77-91.

[6] Boffa, J. M. 2000. Agroforestry Parklands in Sub-Saharan Africa, Bulletin of FAO Conservation. Vol. 34, 258. (in French)

[7] Kelly, B. A., Bouvet, J. M., and Picard, N. 2004. "Size Class Distribution and Spatial Pattern of Vitellaria paradoxa in Relation to Farmers' Practices in Mali." Agroforestry Systems 60 (1): 3-11.

[8] Nikiéma, A. 2005. "Agroforestry Parkland Species Diversity: Uses and Management in Semi-arid West Africa (Burkina Faso)." Ph.D. thesis, Wageningen University, Wageningen, 110.

[9] Wickens, G. E. 1969. "A Study of Acacia albida Del. (Mimosoideae)." Kew Bulletin 23 (2): 181-202.

[10] Roupsard, O., Ferhi, A., Granier, A., Pallo, F., Depommier, D., Mallet, B., Joly, H. I., and Dreyer, E., 1999. "Reverse Phenology and Dry-Season Water Uptake by Faidherbia albida (Del.) A. Chev. in an Agroforestry Parkland of Sudanese West Africa." Functional Ecology 13 (4): 460-72.

[11] Depommier, D. 1996. "Dynamic Structure and Functioning of Faidherbia albida (Del.) A. Chev. Parklands: Characterization and Impact of Biophysical and Anthropogenic Factors on Development and the Future of the Parklands of Dossi and Watinoma, Burkina Faso.” Ph.D. thesis, University Pierre and Marie Curie, Paris VI, France, 519. (in French)
[12] Young, A. 1997. Agroforestry for Soil Management, 2nd ed. Wallingford, UK: CAB Int., 320.

[13] Traoré, K., Ganry, F., Oliver, R., and Gigou, J. 2004. "Litter Production and Soil Fertility in a Vitellaria paradoxa Parkland in a Catena in Southern Mali." Arid Land Research and Management 18 (4): 359-68.

[14] Bationo, A., and Buerkert, A. 2001. "Soil Organic Carbon Management for Sustainable Land Use in Sudano-Sahelian West Africa." Nutrient Cycling in Agroecosystems 61: 131-42.

[15] Bayala, J., Mando, A., Ouedraogo, S. J., and Teklehaimanot, Z. 2003. "Managing Parkia biglobosa and Vitellaria paradoxa Prunings for Crop Production and Improved Soil Properties in the Sub-Sudanian Zone of Burkina Faso." Arid Land Research and Management 17 (3): 283-96.

[16] Hansson, L. 2006. "Comparisons of Infiltrability Capacities in Different Parklands and Farming Systems of Semi-arid Burkina Faso." MSc. thesis, Swedish University of Agricultural Science, Umeå, 20.

[17] Fontes, J., and Guinko, S. 1995. "Map of the Vegetation and the Land of Burkina Faso, Map at 1: 1,000,000+ Notice." University of Toulouse, France, 66. (in French)

[18] Driessen, P., Deckers, J., Spaargaren, O., and Nachtergaele, F. 2001. Lecture Notes on the Major Soils of the World, Soil Resources Reports. Vol. 94. FAO, Rome, 330.

[19] Mathieu, C., and Pieltain, F. 1998. Analysis of Soil Physics. Selected Methods. Lavoisier, Technique and Documentation Edition, Paris, 265. (in French)

[20] Gnankambary, Z., Bayala, J., Malmer, A., Nyberg, G., and Hien, V. 2008. "Decomposition and Nutrient Release from Mixed Plant Litters of Contrasting Quality in an Agroforestry Parkland System in the South-Sudanese Zone of Burkina Faso." Nutrient Cycling in Agroecosystems 82 (1): 1-13.

[21] Gnankambary, Z., Ilstedt, U., Nyberg, G., Hien, V., and Malmer, A. 2008. "Nitrogen and Phosphorus Limitation of Soil Microbial Respiration in Two Tropical Agroforestry Parklands in the South-Sudanese Zone of Burkina Faso: The Effects of Tree Canopy Fertilization." Soil Biology and Biochemistry 40 (2): 350-9.

[22] Philip, J. R. 1957. "The Theory of Infiltration: 4. Sorptivity and Algebraic Infiltration Equations." Soil Science 84: 257-64.

[23] Hillel, D. 1980. Applications in Soil Physics. New York: Academic Press, 385.

[24] Reynolds, W. D., and Elrick, D. E. 1991. "Determination of Hydraulic Conductivity Using a Tension Infiltrometer." Soil Science Society of America Journal 55: 633-9.

[25] Wooding, R. A. 1968. "Steady Infiltration from a 
Shallow Circular Pond.” Water Resources Research 4 (6): 1259-73.

[26] Gardner, W. R. 1958. "Some Steady-State Solutions of the Unsaturated Moisture Flow Equation with Application to Evaporation from a Water Table." Soil Science 85: 228-32.

[27] Ankeny, M. D., Ahmed, M., Kaspar, T. C., and Horton, R. 1991. "Simple Field Method for Determining Unsaturated Hydraulic Conductivity." Soil Science Society of America Journal 55: 467-70.

[28] Haverkamp, R., Ross, P. J., Smettem, K. R. J., and Parlange, J. Y. 1994. "Three-Dimensional Analysis of Infiltration from the Disc Infiltrometer. 2. Physically Based Infiltration Equation." Water Resources Research 30 (11): 2931-5.

[29] Walkley, A., and Black, A. 1934. "An Examination of the Degtjareff Method for Determining Soil Organic Matter and a Proposed Modification of the Chromic Acid Titration Method." Soil Science 37 (1): 29-38.

[30] Rhoades, C. C. 1997. "Single-Tree Influences on Soil Properties in Agroforestry: Lessons from Natural Forest and Savanna Ecosystems." Agroforestry Systems 35 (1): 71-94.

[31] Van Noordwijk, M., Widianto, Heinen, M., and Hairiah, M. 1991. "Old Tree Root Channels in Acid Soils in the Humid Tropics: Importance for Crop Root Penetration, Water Infiltration and Nitrogen Management." Plant and Soil 134 (1): 37-44.

[32] Belsky, A. J., Amundson, R. G., Duxbury, J. M., Riha, S. J., Ali, A. R., and Mwonga, S. M. 1989. "The Effects of Trees on Their Physical, Chemical, and Biological Environments in a Semi-arid Savanna in Kenya." Journal of Applied Ecology 26: 1005-24.

[33] Ouédraogo, E., Mando, A., and Zombré, N. P. 2001. "Use of Compost to Improve Soil Properties and Crop Productivity under Low Input Agricultural System in West Africa." Agriculture, Ecosystems and Environment 84 (3): 259-66.

[34] Gnankambary, Z. 2007. "Compost and Fertilizer Mineralization Effects on Soil and Harvest in Parkland Agroforestry Systems in the South-Soudanese Zone of Burkina Faso." Ph.D. thesis, Swedish University of Agricultural Science, Umeå, 47.

[35] Malmer, A., Johansson, E., and Kluge, M. 1998. "Natural Rehabilitation of Disturbed Tropical Rainforest Soils in Sabah, Malaysia." In Soils of Tropical Forest Ecosystems, edited by Schulte, A., and Ruhiyat, D. Heidelberg: Springer, 199-204.

[36] Ouattara, K., Ouattara, B., Niberg, G., Sedogo, P., and Malmer, A. 2007. "Ploughing Frequency and Compost Application Effects on Soil Infiltrability in a Cotton-Maize (Gossypium hirsutum-Zea mays L.) Rotation System on a Ferric Luvisol and a Ferric Lixisol in Burkina Faso." Soil and Tillage Research 95 (1-2): 288-97.

[37] Savadogo, P., Sawadogo, L., and Tiveau, D. 2007. "Effects of Grazing Intensity and Prescribed Fire on Soil Physical and Hydrological Properties and Pasture Yield in the Savanna Woodlands of Burkina Faso." Agriculture, Ecosystems and Environment 118: 80-92.

[38] Ouattara, K. 2007. "Improved Soil and Water Conservatory Managements for Cotton-Maize Rotation System in the Western Cotton Area of Burkina Faso." $\mathrm{Ph}$.D. thesis, Swedish University of Agricultural Science, Umeå, 50.

[39] Hoogmoed, W. B., and Stroosnijder, L. 1984. "Crust Formation on Sandy Soils in the Sahel I. Rainfall and Infiltration." Soil and Tillage Research 4 (1): 5-23. 